\title{
A new pest: Rush veneer, Nomophila noctuella Denis \& Schiffermüller, 1775 (Lepidoptera: Crambidae) on alfalfa (Medicago sativa L.) and its larval parasitoids in Iğdır province of Turkey ${ }^{1}$
}

\author{
Iğdır ilinde yoncada (Medicago sativa L.) yeni bir zararlı, Nomophila noctuella Denis \& \\ Schiffermüller, 1775 (Lepidoptera: Crambidae) ve larva parazitoitleri
}

\section{Celalettin GÖZÜAÇIK ${ }^{2}$}

\author{
Erol ATAY ${ }^{3}$
}

\begin{abstract}
Summary
Rush Veneer, Nomophila noctuella Denis \& Schiffermüller, 1775 (Lepidoptera: Crambidae) is a pest fed with grass-pasture forage plants in many countries. The aim of this study was to determine damage state, and larvae parasitoids of $N$. noctuella found at alfalfa (Medicago sativa L.) fields of Iğdır province in the years 2014-2015. For this aim, a survey was performed every 3-7 days in April-June and September-December months. In the survey, each field was monitored and the larvae were collected from alfalfa fields and kept in boxes covered with nets in the laboratory at $25 \pm 1{ }^{\circ} \mathrm{C}$ and $65 \pm 5 \% \mathrm{RH}$. and following pupation, adult moths and larvae parasitoids were obtained. During the survey conducted at alfalfa fields, the larvae of the pest preferred alfalfa fields planted in April month and damaged the plantation at changing rates by cutting-eating them from 3-5 cm upper part of root of alfalfa plants at the height of $7-10 \mathrm{~cm}$. Of larvae cultivated in the laboratory, Chelonus oculator (Fabricius, 1775) C. inanitus (Linnaeus, 1767) parasitoids belonging to Braconidae (Hymenoptera) family were also obtained in the study. As a result, the present study revealed that Rush Veneer, $N$. noctuella for alfalfa plants was a new pest recorded for the first time in Turkey. $N$. noctuella is the new host of $C$. oculator and $C$. inanitus in the world.
\end{abstract}

Key words: Nomophila noctuella, new pest, larval parasitoids, alfalfa, Iğdır

\section{Özet}

Nomophila noctuella Denis \& Schiffermüller, 1775 (Lepidoptera: Crambidae) birçok ülkede çayır-mera yem bitkileriyle beslendiği bilinmektedir. Bu çalışma, Iğdır ili yonca (Medicago sativa L.) alanlarında zarar yaptığı belirlenen N. noctuella 'nın zararını ve doğal düşmanlarını belirlemek amacıyla 2014-2015 yıllarında yürütülmüştür. Çalışmalar, Nisan-Haziran ve Eylül-Ekim aylarında 3-7 gün aralıklarla yeni ekilmiş yonca alanlarına gidilerek gözlemler yapılmış ve her tarladan larvalar toplanarak $25 \pm 1^{\circ} \mathrm{C}$ ve $65 \pm 5 \% \mathrm{RH}$ ortamında kültüre alınmıştır. Çalışmalarda, zararlının Nisan ve Eylül aylarında yeni ekilmiş yonca bitkilerini tercih ettiği, 7-10 cm boya ulaşmış bitkinin kökten 3-5 cm yukarısından keserek beslendiği tespit edilmiştir. Zararlının parazitoiti olarak Chelonus oculator (Fabricius, 1775) ve C. inanitus (Linnaeus,1767) (Hymenoptera, Braconidae) türleri elde edilmiştir. N. noctuella'nın Türkiye'de yonca bitkisinde yeni bir zararlı olduğu ve elde edilen parazitoitler içinde yeni bir konukçusu olduğu belirlenmiştir.

Anahtar sözcükler: Nomophila noctuella, yeni zararlı, larva parasitoitleri, yonca, Iğdır

\footnotetext{
${ }^{1}$ Partly presented as poster and published summary in book at Challenges in Modern Agricultural Production, Skopje, Makedonia, 11 December 2014

${ }^{2}$ Igdir University Faculty of Agriculture, Department of Plant Protection, 76000, Iğdır, Turkey

${ }^{3}$ Mustafa Kemal University, Faculty of Arts and Sciences, Department of Biology, 31000, Antakya, Turkey

* Corresponding author (Sorumlu yazar) email: cgozuacik46@gmail.com

Received (Alınış):20.01.2016 Accepted (Kabul ediliş):15.03.2016 Published Online (Çevrimiçi Yayın Tarihi):26.12.2016
} 


\section{Introduction}

The genus Nomophila (Lepidoptera, Crambidae) comprises of 17 identified species distributed across North America, South America, Africa, Europe, temperate Asia, the Oriental region and Australia. Rush Veneer, Nomophila noctuella Denis \& Schiffermüller, has wingspan 26-32 mm. At the time of the rest, wing of moth has a very elongated and narrow shape, which makes it easily recognizable. The mature larvae of the species are 15 to $20 \mathrm{~mm}$ long, gray green and spotted. Larvae vary between 13 and $22 \mathrm{~mm}(1 / 2$ to $7 / 8 \mathrm{inch})$ in length. A significant damage symptom is a silk thread leading from the tunnel to the base of the clipped seedling (Philip et al. ,1990). There are two to four generations per year )Furniss \& Carolin, 1977). The larvae feed with clover, polygonum, wheat and vaccinium (Drake \& Decker, 1927). At the same time, Anjos et al. (1986), Teixeira et al. (1999) and Zanuncio et al. (2001) addressed that the pest damaged Eucalyptus seedlings and Pseudotsuga menziesii var. glauca (Johnson \& Duffield, 1961). In 1919, the insect seriously damaged newly seeded fields of sweet clover in Illinois. Virtually, damage of this insect is reported in every year for some locations in Illinois (Flint, 1922). In literature, some authors reported faunistic and zoological knowledge of the insect from Turkey in the past (Koçak, 2001; Atay, 2005; Aytekin \& Kütük, 2011). However, the data published on the damage of the insect is scanty in Turkey. Therefore, the aim of this work was to investigate damage state and larvae parasitoids of $N$. noctuella that harmfully influences alfalfa (Medicago sativa L.) fields of Iğdır province in the years 2014-2015.

\section{Material and Method}

This study was conducted with the objective to determine damage state and larvae parasitoids of Rush Veneer, Nomophila noctuella Denis \& Schiffermüller found at four alfalfa (Medicago sativa L.) fields of Aralık district (Tazeköy and Yukarı Çiftlik) of Iğdır province between April-June and SeptemberDecember in 2014 and 2015. In the survey, each field was monitored every 3-7 days in April-June and September-December months and the larvae were collected from alfalfa fields and kept in boxes covered with nets in the laboratory at $25 \pm 1^{\circ} \mathrm{C}$ and $65 \pm 5 \%$ r.h. and adult moths and larvae parasitoids were obtained. Adult of $N$. noctuella was identified by Erol Atay. Obtained parasitoids species were identified by Prof. Dr. Ahmet Beyarslan (Bitlis Eren University, Faculty of Arts and Science, Department of Biology, Bitlis/ Turkey) as Chelonus inanitus and C. oculator.

\section{Results and Discussion}

The Rush Veneer, Nomophila noctuella is a cosmopolitan species. It has been recorded in Cyprus, Syria, Lebanon, Israel, Arabian peninsula, Iraq, Iran, Pakistan, India, Chinese, Japan (Munroe, 1973), Iceland, Norway, Denmark, Swiss, East Europe, Indonesia, Lithuanian, Poland, Czech Republic, The Netherlands, Britain, Ireland, Belgium, Luxembourg, France, Spain, Italy, Austria, Hungary, Yugoslavia, Romania, Bulgaria, Albania, Greece, Swedish (Svensson, 1999), Turkey (Karsholt \& Razowski, 1996; Medvedev, 1997; Koçak, 2001; Atay, 2005), and Balkan Peninsula (Fazekas, 2009). Distribution of $N$. noctuella in Turkey has been reported by Koçak \& Kemal (2009) (Figure 1).

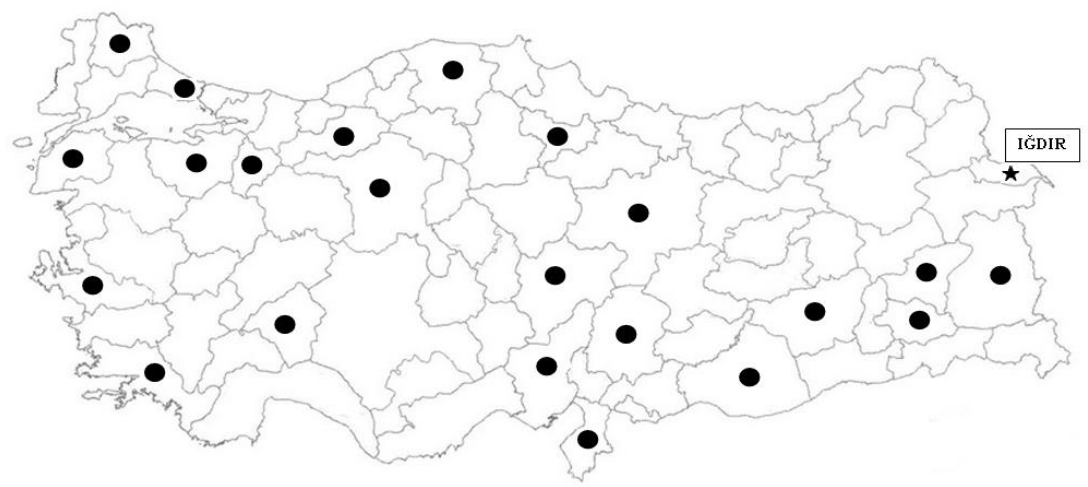

Figure 1. Distribution of Nomophila noctuella in Turkey (Koçak \& Kemal 2009). 
The damage of the pest on alfalfa (Medicago sativa L.) fields in Aralık district of Iğdır province has not yet been documented in Turkey until now. In this research, the damage of the larvae of the pest preferred alfalfa fields planted in April month was examined for Tazeköy (39 $55^{\prime} 35^{\prime \prime} \mathrm{N}, 44^{\circ} 30^{\prime} 57^{\prime \prime} \mathrm{E}, 822 \mathrm{~m}$ ) and Yukarı Çiftlik $\left(39^{\circ} 51^{\prime} 38^{\prime \prime} \mathrm{N}, 44^{\circ} 34^{\prime} 33^{\prime \prime} \mathrm{E}, 817 \mathrm{~m}\right)$ of Aralık distinct of the province. The pest has damaged the plantation at varying rates by feeding leaves and by cutting-eating them from $3-5 \mathrm{~cm}$ upper part of the root of alfalfa plants at the height of $7-10 \mathrm{~cm}$. In agreement with the present study, Smith (1942) reported that the damage was done by eating irregular shallow excavations on the stalk usually covering the area with silk. The larvae were surface feeders and did not burrow into the stalk. In addition, when prodded, they moved equally well backward or forward in their burrow. From the present study, it was understood that the larvae during the daytime have hidden within gallery under especially parts of corn stalks or other plant residues in the field, as also confirmed by Ellis (1925) for two generations of the pest in New England. In relation to the present findings, it was observed that $N$. noctuella over winters at mature larval stage within tunnel under plant residues, which was similar to those of Flint (1922) in New York, and Zanuncio et al. (1999). In respect to the present findings, the larvae in sunless hours of the days has fed with fresh plants around the places where they hidden (Figure 2). Additionally, therein, they have been pupae within cocon in the gallery. Zanuncio et al. (1999) announced that the presence of the pest for two to four generations per year could show variability with respect to the regions. It was observed to be only two generations of the pest for the Iğdır microclimate condition. The difference may be ascribed to climatic conditions. Due to the fact that the larvae fed with alfalfa plants in the fields, sporadic spaces have been observed in the fields. Aiming to prevent the damage, farmers have adopted chemical controls or made re-plantation therein. Due to economic losses, it is very important to conduct further investigations on the damage levels of the pest, found commonly in the alfalfa fields of Iğdır province.
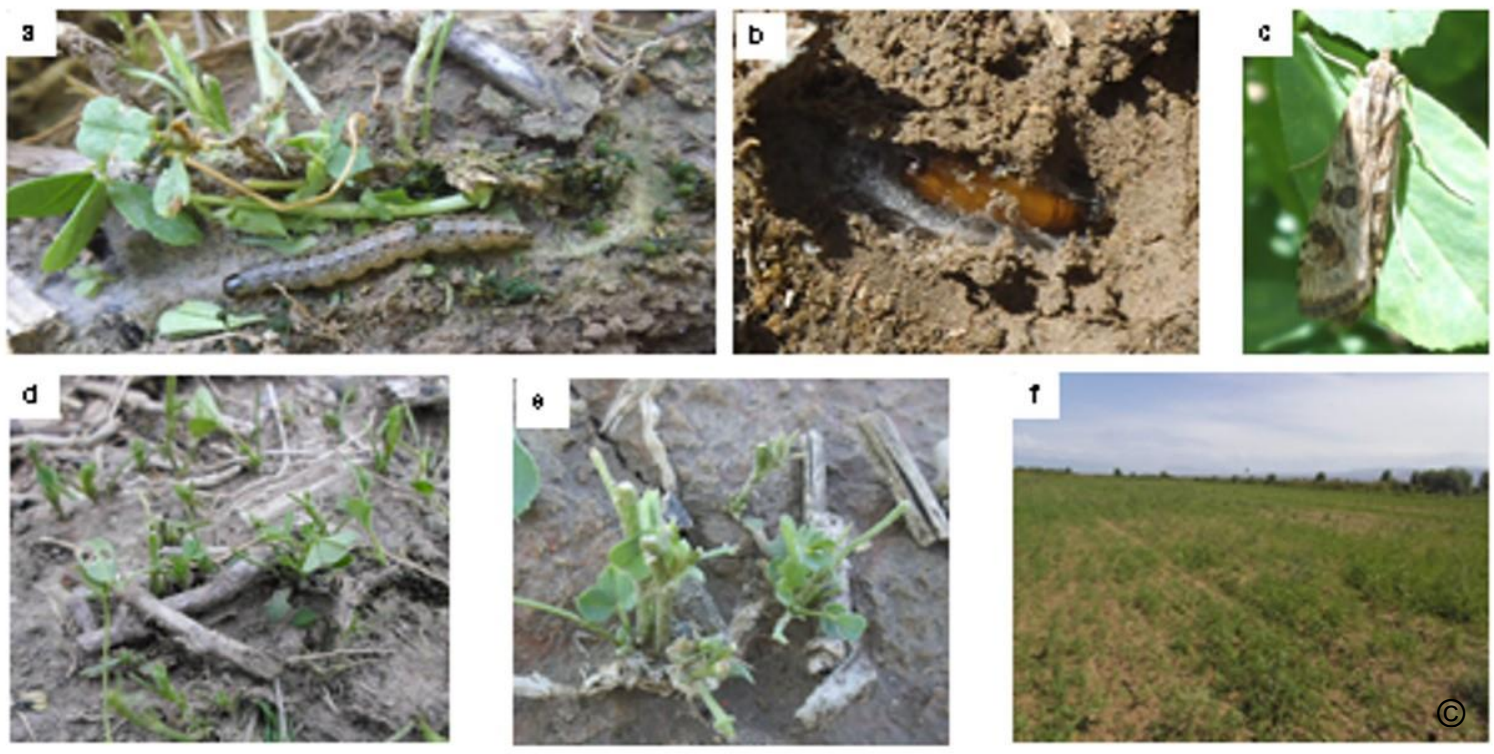

Figure 2. The larvae (a), pupa (b), adult (c) and damaged (d, e, f) of Nomophila noctuella.

From the study, the new findings illustrated that the pest damaged the alfalfa fields planted newly across Aras River, Armenian border especially during spring and autumn seasons. It was determined that the adults of $N$. noctuella flied about the alfalfa fields up to the mid-September.

Parasitoids of Nomophila sp. were identified by Zanuncio et al. (1999), and it was reported that Diplazon laetatorius (Fab.) and Eiphosoma sp. two species of the Porizontini and Mesostenini tribes, all of which are peculiar to the Ichneumonidae family of Hymenoptera. Besides, Yu et al. (2012) reported that parasitoids of $N$. noctuella were Cotesia pyralidis (Muesebeck, 1921) Meteorus cinctellus (Spinola 1808), Meteorus rubens (Nees, 1811). 
In this studies, the primary mortality factors of the rush veneer were determined to be two species of parasitoids belonging to Braconidae family of Hymenoptera. The parasitoids are Chelonus inanitus

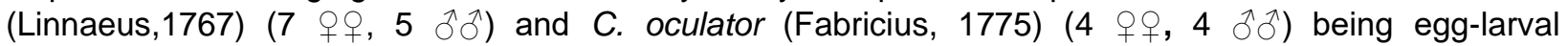
parasitoids. They were reared for the first time from larvae of $N$. noctuella. Detailed information about the two egg-larval parasitoid species of $N$. noctuella was;

\section{Chelonus inanitus (Linnaeus,1767)}

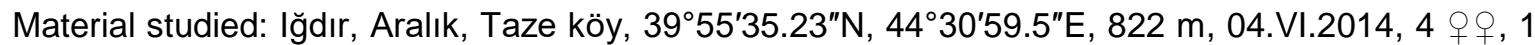

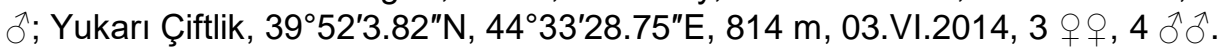

Hosts: Agrotis segetum (Schiff.) Spodoptera exigua (Hübner, 1808) (Modarres, 1997; Shojai, 1998; Khanjani, 2004); Spodoptera littoralis (Boisduval, 1833), (Lepidoptera: Noctuidae) (Tomkins et al., 1987; Wharton et al., 1998), Phthorimaea operculella (Zeller) (Lepidoptera: Gelechiidae), Etiella zinckenella (Treitschke, 1832) (Lepidoptera: Phycitidae) (Balevski, 1998); Mesoligia literosa (Haworth, 1809), Chortodes elymi (Treitschke, 1825), Eucosma aemulana (Schläger, 1849), S. tripoliana (Barrett, 1880) (Lepidoptera: Tortricidae) (Watanabe, 1937); Aethes francillana (Fabricius, 1794) (Lepidoptera: Tortricidae); Haritalodes derogata (Fabricius, 1775) (Lepidoptera: Crambidae); Ostrinia nubilalis (Hubner, 1796) (Lepidoptera: Pyraustidae); Oligia strigilis (Linnaeus, 1758), Leucania loreyi (Duponchel, 1827), Peridroma saucia (Hubner, 1808), , Pseudaletia unipuncta (Haworth, 1809) (Lepidoptera: Noctuidae) (Yu et al., 2012). Nomophila noctuella (Denis\& Schiffermüller, 1775) (new host record).

Distributions: Albania, Algeria, Armenia, Belgium, Bulgaria, Croatia, Cyprus, Czech Republic, former Czechoslovakia, former Yugoslavia, Denmark, Egypt, Finland, France Germany, Greece, Hungary, Iran, Ireland, Israel, Italy, Korea, Latvia, Lithuania, Mongolia, Netherlands, Norway, Poland, Romania, Russia, Slovakia, Slovenia, Spain, Sweden, Switzerland, Turkey (Yu et al., 2005), Turkey: Adapazarı, Afyon, Amasya, Balıkesir, Bilecik, Bursa, Canakkale, Çorum, Edirne, İçel, Kastamonu, Kayseri, Kırklareli, Tekirdağ (Aydoğdu \& Beyarslan, 2002; Beyarslan, 1985; Beyarslan et al., 2002; Kohl, 1905).

\section{Chelonus oculator (Fabricius, 1775)}

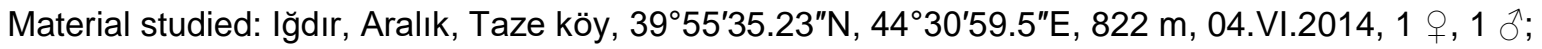

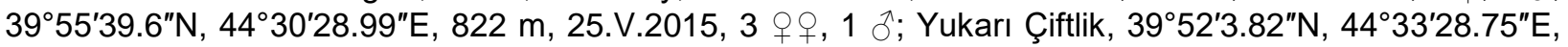
$814 \mathrm{~m}, 03 . \mathrm{VI} .2014,2$ ऊ̂े.

Hosts: Agrotis segetum (Denis \& Schiffermuller, 1775), Chortodes elymi (Treitschke, 1825), Spodoptera exigua (Hubner, 1808), Helicoverpa armigera (Hubner, 1809), Heliothis peltigera (Denis \& Schiffermuller 1775), Heliothis viriplaca (Hufnagel, 1766), (Lepidoptera: Noctuidae); Etiella zinckenella (Treitschke, 1832) (Lepidoptera: Phycitidae); Coleophora anatipennella (Hubner, 1796) (Lepidoptera: Coleophoridae); Loxostege sticticalis (Linnaeus, 1761) (Lepidoptera: Pyraustidae); Zeiraphera isertana Fabricius, 1794 (Lepidoptera: Tortricidae) (Tobias, 1995). Spodoptera littoralis (Boisduval, 1833), Ephestia kuehniella Zeller, 1879 (Özkan \& Özmen, 2001). Cydia corticana Hubner (Lepidoptera: Tortricidae); Leucania loreyi (Duponchel, 1827) (Lepidoptera: Noctuidae); Homoeosoma nebulella (Denis \& Schiffermuller, 1775); Ostrinia nubilalis (Hubner, 1796) (Lepidoptera: Pyralidae (Yu et al., 2012). Nomophila noctuella (Denis\& Schiffermüller, 1775) (new host record).

Distribution: Afghanistan, Albania, Azerbaijan, Belgium, Bulgaria, Croatia, Czech Republic, former Czechoslovakia, former Yugoslavia Finland, France, Georgia, Germany, Greece, Hungary, Iran, Italy, Kazakhstan, Latvia, Lithuania, Moldova, Mongolia, Netherlands, Norway, Poland, Romania, Russia, Slovakia, Slovenia, Spain, Sweden, Switzerland, Tajikistan, Turkey, Turkmenistan, Ukraine, United Kingdom, Uzbekistan (Yu et al., 2005), Caucasus, Kazakhstan, Central Asia, North Africa, Iran, and Western Europe (Tobias, 1995), Turkey (Özkan \& Özmen 2001; Aydoğdu \& Beyarslan, 2002).

As a result, the present study revealed that Rush Veneer, $N$. noctuella for alfalfa plants was a new pest recorded for the first time in Iğdır province of Turkey. More particularly, the pest damaged the alfalfa fields sown newly during spring and autumn seasons. Also, $N$. noctuella is the new host of $C$. oculator and $C$. inanitus in the world. Further studies are still required for better determining damage of the pest, 
and especially more effective pest control in alfalfa fields. We recommend that farmers take necessary measures on reducing the damage of the pest for alfalfa fields cultivated newly.

\section{References}

Anjos, N., G.P. Santos \& J.C. Zanuncio, 1986. Pragas do eucalipto e seu controle. Informe Agropecuario, Belo Horizonte, 12(141): 50-58.

Atay, E., 2005. Adana, Mersin, Osmaniye İllerinde Bulunan Pyraloidae (Lepidoptera) Faunası Üzerine Taksonomik ve Sistematik Çalışmalar. Doktora tezi, Adana, 267s.

Aydoğdu, M. \& A. Beyarslan, 2002. Chelonus Jurine (Hymenoptera: Braconidae: Cheloninae) Species of the Marmara Region. Turkish Journal of Zoology, 26(1): 1-13.

Aytekin, H.U. \& M. Kütük, 2011. Gaziantep İli Crambidae (Lepidoptera: Pyraloidae) Faunasının Belirlenmesi. Kafkas Üniversitesi Fen Bilimleri Enstitüsü Dergisi, 4(1): 9-16.

Balevski, N.A., 1998. Catalogue of the braconid parasitoids (Hymenoptera: Braconidae) isolated from various phytophagous insect hosts in Bulgaria. Sofia-Moscow, $126 \mathrm{pp}$.

Beyarslan, A., 1985. Türkiye'nin Akdeniz bölgesinde saptanan Cheloninae (Hymenoptera; Braconidae) türleri ve yayılışı. Doğa Bilimler Dergisi, A2, 9: 12-19.

Beyarslan, A., F. İnanç, Ö. Çetin \& M. Aydoğdu, 2002. Braconiden von den türkischen Inseln Imbros und Tenedos (Hymenoptera, Braconidae, Agathidinae, Braconinae, Cheloninae, Microgastrinae). Entomofauna 23(15): 173-188.

Drake, C.I. \& G.C. Decker, 1927. Some caterpillars frequently mistaken for European corn borer. lowa State College of Agriculture and Mechanic Arts. Agricultural Experiment Station Circular, 16 pp.

Ellis, W.O., 1925. Some Lepidopterous larvae resembling the European corn borer. Journal of Agricultural Research 30(8): 777-792.

Fazekas, I., 2009. Contribution to the Microlepidoptera fauna of Balkans, Nr. 1 (Lepidoptera). Natura Somogyiensis, (15) 181-194.

Flint, W.P., 1922. Studies of the life history of Nomophila noctuella. Annals of the Entomological Society of America 15: 154-156.

Furniss, R.L. \& V.M. Carolin, 1977. Western Forest Insects. U.S.D.A. Forest Service. Miscellaneous Publication No. 1339. $654 \mathrm{pp}$.

Johnson, N.E. \& J.W. Duffield, 1961. Larvae of Nomophila noctuella feeding on Douglas-fir nursery seedlings. Journal of Economic Entomology 54:1249-1258.

Karsholt, O. \& J. Razowski, 1996. The Lepidoptera of Europe Distributional Checklist, Apollo Books. Denmark. 380s.

Khanjani, M. 2004. Field crop pests in Iran. Bu-Ali Sina University, No. 195, 1-719.

Khanjani, M., 2006. Vegetable pests in Iran. Bu-Ali Sina University, No. 205, 1-467.

Koçak, A.Ö., 2001. Tentative.Checklist of Turkısh Lepidoptera. Revised checklist of the Lepidoptera of Turkey. Centre for Entomological Studies, Ankara, 17: 1-150.

Koçak, A.Ö. \& M. Kemal, 2009. Revised checklist of the Lepidoptera of Turkey. Centre for Entomological Studies, Ankara, 17: 1-150.

Kohl, F.F., 1905. Hymenopteren. In: Penther A. \& Zederbauer E., Ergebnisse einer naturwissenschaftlichen Reise zum Erdschias Dagh. (Klein Asien). Annalen Naturhistorischen Hofmuseums, 20: 220-246.

Medvedev, G.S., 1997. Keys to the Insects of the European Part of the USSR. Science Publishers, USA, 690 pp.

Modarres, A.M., 1997. Family Braconidae (Hymenoptera), pp. 265-267. — In: (ed.) List of agricultural pests and their natural enemies in Iran. Ferdowsi University Press, $427 \mathrm{pp}$.

Munroe, E.G., 1973. A supposedly cosmopolitan insect: the celery webworm and allies, genus Nomophila Hübner (Lepidoptera: Pyralidae: Pyraustinae). Canadian Entomologist 105(2):177-216.

Özkan, C. \& D. Özmen, 2001. A new record for Turkish fauna Chelonus oculator Panzer (Hymenoptera: Braconidae) and its two new hosts. Turkish Journal of Entomology 25(4): 263-265. 
A new pest: Rush veneer, Nomophila noctuella Denis \& Schiffermüller, 1775 (Lepidoptera: Crambidae) on alfalfa (Medicago sativa L.) and its larval parasitoids in Iğdır province of Turkey

Philip, B.H., J.C. Sally \& M.H. Everett, 1990. Growing healthy seedlings: identification and management of pests in Northwest forest nurseries. 110 pp.

Svensson, I., 1999. Remarkable records of Microlepidoptera in Sweden during 1998. Entomologisk Tidskrift 120(1/2): 23-35.

Smith, R.C., 1942. Nomophila noctuella as a grass and alfalfa pest in Kansas. Journal of the Kansas Entomological Society, 15(1): 25-34.

Shojai, M., 1998. Entomology (ethology, social life and natural enemies) (biological control) III. Tehran University Publications, $550 \mathrm{pp}$.

Teixeira, C.A.D., J.C. Zanunclo, M.F. Sossai \& D. Pratissoli, 1999. Biologia da lagarta-rosca Nomophila sp. (Lepidoptera: Pyralidae) em mudas de Eucalyptus grandis (Myrtaceae): fases do ovo e larva. Revista Árvore, Viçosa-MG, 23(1): 65-68.

Tobias, V.I., 1995. Keys to insects of the European part of the USSR. Volume III. Hymenoptera, Part IV. Braconidae. G.S. Medvedev, ed.-in-chief. Amerind Publishing Co., New Delhi. 883 pp.

Watanabe, C., 1937. A contribution to the knowledge of the braconid fauna of the Empire of Japan (Hymenoptera). Journal of the Faculty of Agriculture, Hokkaido Imperial University, 42(1):1-188.

Yu, D.S., C.V. Achterberg \& K. Horstmann, 2005. World Ichneumonoidea 2004. Taxonomy, biology, Morphology and distribution [Braconidae]. Taxapad 2005 (Scientific names for information management) Interactive catalogue on DVD/CDROM. Vancouver.

Yu, D.S., C.V. Achterberg \& K. Horstmann, 2012. Taxapad 2012, Ichneumonoidea 2011. Database on flashdrive. www.taxapad.com, Ottawa, Ontario, Canada.

Zanuncio, J.C., C.A.D. Teixeira \& M.F. Sossai, 1999. Natural enemies of Nomophila sp. (Lepidoptera: Pyralidae), a cut-worm of Eucalyptus grandis (Myrtaceae) seedlings in Viçosa, Minas Gerais, Brazil. Anais da Sociedade Entomológica do Brasil, 28(2): 357-358.

Zanuncio, J.C., M.F. Sossai, T.V. Zanuncio \& C.A.D. Teixeira, 2001. Influência da idade da muda de Eucalyptus grandis no desenvolvimento da lagarta-rosca Nomophila sp. Pesquisa Agropecuária Brasileira, 36(5): 743750. 